\title{
In situ Ac Impedance Measurement during Galvanostatic Deposition and Dissolution of Lithium
}

\author{
Tetsuya OSAKA*, Toshiyuki MOMMA and Takayuki TAJIMA
}

Received November 9, 1993 ; Accepted January 5, 1994

\section{Introduction}

Recently, a rechargeable lithium battery is noticed as candidates for high performance batteries. The evaluation and development of lithium anode are one of the most important point due to its dendritic deposition and the side reaction between electrolyte solution and the anode. The ac impedance measurement in the open circuit potential is one of the powerful method for evaluation of the clectrode in cell $1^{1,2)}$. However, for further evaluation of the clectrode, it is very useful to operate in-situ ac impedance measurement during charging or discharging process of cell or battery. A few papers were published for the ac impedance measurcment during galvanostatic polarization $^{3,4}$ ). In this communication, we propose it for evaluating lithium anode charging and discharging process and discuss whether the in-situ method is more effective than the ex-situ one.

\section{Experimental}

Reagent grade propylene carbonate (PC) with 1.0 mol dm ${ }^{-3} \mathrm{LiClO}_{4}$ was used as electrolyte solution. Charging and discharging were measured with a working electrode of lithium deposited on nickel substrate, and a reference electrode of $\mathrm{Li} / \mathrm{Li}^{+}$. The insitu ac impedance measurement was carried out during the cyclc of galvanostatic charging and discharging. The cycle was opcrated according to the procedure proposed by Koch et al., ${ }^{5}$ ) that is, lithium deposited at $1 \mathrm{~mA} \mathrm{~cm}^{-2}$ and $1 \mathrm{C} \mathrm{cm}^{-2}$ was dissolved and deposited at $0.2 \mathrm{C} \mathrm{cm}^{-2}$ and the same current density. The ac current of $10 \mu \mathrm{A}$ (zero to peak) was applied to the electrochemical cell with de current by a galvanostat (Hokuto Denko HA-501G) equipped to a computer and potential response was analyzed by a

Department of Applied Chemistry, School of Science and Engineering; Kagami Memorial Laboratory for Materials Science and Technology, Waseda University, Shinjuku-ku, Tokyo, 169, Japan

Key words; Ac impedance mcasurement, Ac current, In-situ measurement, Rechargeable lithium battery frequency response analyzer (NF Electric Instruments FRA S-5720C). The frequency range was covered from $10 \mathrm{~Hz}$ to $20 \mathrm{kHz}$. All measurements were performed under a dry argon gas atmosphere.

Results and Discussion

Figure 1 shows Cole-Cole plots obtained by the int-situ impedance measurement during galvanostatic $\mathrm{Li}$ deposition process at $1 \mathrm{~mA} \mathrm{~cm} \mathrm{~cm}^{-2}$. The impedance spectra display semi-circles in higher frequency region, representing the electrode reaction during charging. The measurement during the cycle is expected to enable to avoid the time dependence of the $R_{c 1}$ value due to the measurement after the stop of the reaction. The charge transfer resistance $\left(\mathrm{R}_{\mathrm{ct}}\right)$ due to $\mathrm{Li}$ deposition is estimated from the diameter of the semi-circle ${ }^{2)}$. The value is plotted against the deposition charge of $\mathrm{Li}$ as shown in Fig.1(b) with results of the ex-situ impedance measured at the open circuit potential by the superposition of the ac voltage. It is

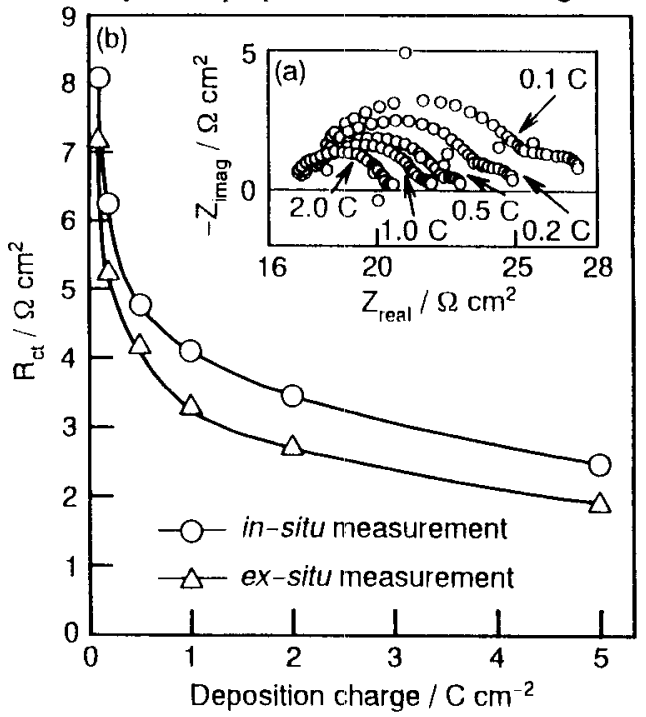

Fig.1 In-situ impedance mcasurements for electrodeposited lithium during galvanostatic charging at $1 \mathrm{~mA}$ $\mathrm{cm}^{-2}$. (a)Cole-Cole plots (b)The dependence of charge transfer resistance $\left(R_{c 1}\right)$ on deposition charge. 
appeared that the influence of the overpotential for the charging on the change of $R_{c t}$ value obtained by the in-situ measurement is small, since the change of the overpotential is small. It is difficult to detcrmine the origin of the difference, though the difference is small, between the values obtained by the in-situ and ex-situ measurements, since the value is influeneed by the many factors, such as the overpotential, the products of the side reaction, the surface morphology and so on. The change of $R_{c t}$ determined with the insitu measurement against deposition charge shows the same tendency as that obtained by the ex-situ onc.

Figure 2 shows the results of the in-situ impedince measurcments for cach cycle of charging and discharging processes. In Figs.2(a) and (b), impedance spectrum for charging is similar to that for discharging. On the other hand, the spectrum for charging in Fig.2(c) becomes different from that for discharging, and both $\mathrm{R}_{c t}$ values for charging and discharging become much larger than the values in Figs.2(a) and (b). The behavior is more clearly shown in Fig.3, where the $\mathrm{R}_{\mathrm{cr}}$ with the elcetric doublc layer capacitance $\left(\mathrm{C}_{\mathrm{dl}}\right)$ and the time constant $\left(\tau=\mathrm{R}_{\mathrm{ct}} \cdot \mathrm{C}_{\mathrm{dl}}\right)$ arc shown. The three factors begin to change in the cyeles when the life in the anode approaches to the end, that is, the discharge potential reaches at $1 \mathrm{~V} \mathrm{vs}$. $\mathrm{Li} / \mathrm{Li}^{+}$, and after the cycles the $\mathrm{R}_{\mathrm{c}}$ and the $\tau$ sharply increasc and the $C_{\text {II }}$ decreases. These results showed that the conditions in lithium anode change about the end of the life of the anode. Therefore, it is proved that the in-situ ac impedance measurement is the effective method to trace the change of the conditions in the anode during the opelation.

\section{Conclusion}

When the cycles of charging and discharging processes at $1 \mathrm{~mA} \mathrm{~cm}{ }^{-2}$ approach to the end of the life in the anode, the charge transfer resistance changes drastically. Thus, the in-situ ac impedance neasurement during galvanostatic polarization is proved to be very cffective for tracing and quickly evaluating the conditions of the lithium anode during the processes.

\section{References}

1) J.G.Thevenin and R.H.Muller, J.Electrochem.Soc., 134, 273(1987).

2) T.Osaka, T.Momma, K.Nishimura and T.Tajima, J.Elcctrochem.Soc., 140, 2745(1993).

3) P.Chenebault, D. Vallin, J.Thevenin and R. Wiart, J.Appl.Electrochem., 19, 413(1989).

4) Z.Stoinov, B.Savova-Stoinov and T.Kossev, J.Power Sources, 30, $275(1990)$.

5) J.L.Goldman, R.M.Mank, J.H.Young and V.R.Koch, J.Electrochem.Soc., 127, 1461(1980).
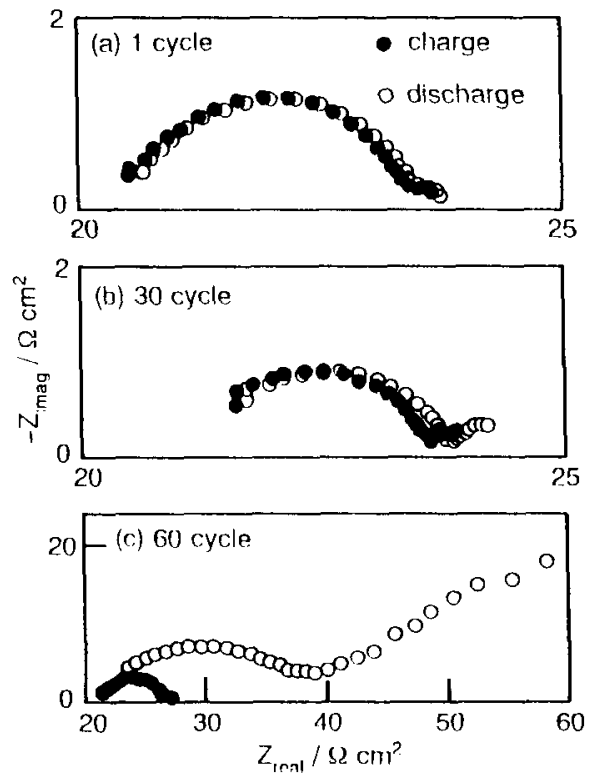

Fig.2 In-siru impedance spectsa in each cycle at 1 mA cm$n^{-2}$ and $1 \mathrm{C} \mathrm{cm}^{-2}$.

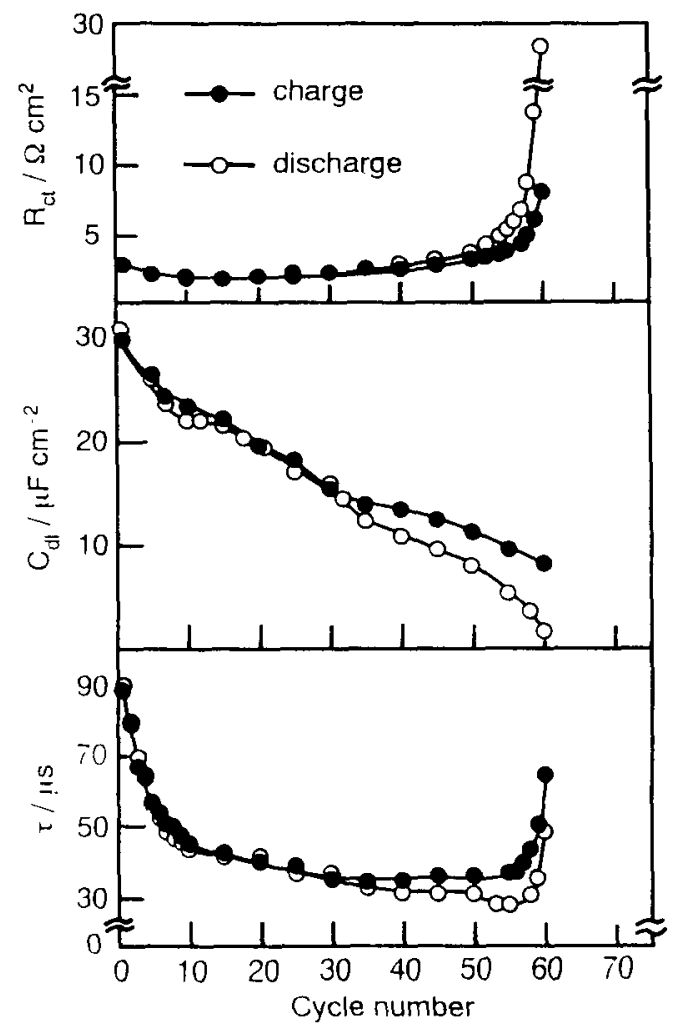

Fig. 3 Variations of clarge transfer resistance $\left(\mathrm{R}_{\mathrm{Cl}}\right)$, clectric double layer capacitance $\left(\mathrm{C}_{\mathrm{d1}}\right)$, and time constant $(\tau)$ with cycle number during galvanostatic charging and discharging processes. 